\title{
Body Mass Index and Waist Circumferences Related to Uric Acid Level among Adults
}

\author{
Arindha Reni Pramesti ${ }^{1}$, Walliyana Kusumaningati ${ }^{2 *}$ \\ 1) Medical Technology Cluster, Indonesian Medical Education and Research Institute (IMERI), Faculty of Medicine, \\ Universitas Indonesia \\ 2) Nutrition Program Study, Faculty of Medicine and Health, University of Muhammadiyah Jakarta \\ *walliyanakusumaningati@gmail.com
}

\begin{abstract}
Background: the changes in metabolism in the body can trigger the increase of uric acid levels which can lead to a precursor of hyperuricemia and gout disease that can result extreme pain in the joint. Based on the study, it has known that uric acid levels can be caused by obesity, protein intake, lifestyle, and others. The anthropometric method which usually used to measured obesity are body mass index (BMI) and waist circumference (WC). Currently, the most commonly used ratio in this way is the Body Mass Index (BMI). Result: in a Canadian study among 151 adults, it was reported that there was a higher correlation between the area of abdominal visceral fat and WC compared with the correlation with the waist-hip circumference ratio. WC is also more strongly associated with total body fat, measured by densitometry, than by waist-to-hip circumference ratio. High levels of leptin in obese people can cause uric acid disruption through urine, so that uric acid levels in the blood of obese people become high. BMI also shows a positive relationship with leptin concentration, which is a trigger factor to increased uric acid levels. American adults also shown that uricemia related to their BMI value. Conclusion: BMI is one of the indicators of obesity, while obesity often thought to influence the incidence of gout by increasing uric acid levels in the blood. WC also closely related potentially to atherogenic metabolic disorders associated with abdominal obesity that to waistto-hip circumference ratios.
\end{abstract}

Keywords: Uric Acid Level, Body Mass Index, Waist Circumference.

\section{INTRODUCTION}

The changes in metabolism in the body can trigger the increase of uric acid levels which can lead to a precursor of hyperuricemia and gout disease (1). Uric acid is a waste product from the balancing of human purine. This uric acid is developed by adenosine, inosine, hippoksentie, adenine, and guanine (2). Purine from diet intake during nucleic acid catabolism is converted to uric acid directly. The breakdown of purine nucleotides occurs in all cells, but uric acid only produced by tissues that contain xanthine oxidase, especially the liver and small intestine (3).

Uric acid levels that experience an increase above normal are called hyperuricemia. Most epidemiological studies mention that hyperuricemia occurs when serum uric acid levels in adults are more than $7.0 \mathrm{mg} / \mathrm{dl}$ for men and more than $6.0 \mathrm{mg} / \mathrm{dl}$ for women (3). Increased levels of uric acid in the body can result in extreme pain in the joint (4). If this 
condition occurs continuously for a long time it can cause damage to joints, soft tissues, and kidneys (3).

Based on the study, it has known that uric acid levels can be caused by obesity, protein intake, lifestyle, and others. The anthropometric methods which usually used to measured obesity is body mass index (BMI) and waist circumference (WC).

In this literature review, the uric acid level which is affected by BMI and WC will be discussed further.

\section{LITERATURE REVIEW}

\section{Body Mass Index as an Indicator of Obesity}

Weight-height ratio indicated the relationship between weight and height and it is used to determine overweight and obesity status among adults, so this ratio is sometimes referred to as the obesity index. Currently, the most commonly used ratio in this way is the Body Mass Index (BMI). BMI calculating body weight in kilograms divided by height in meters squared $\left(\mathrm{kg} / \mathrm{m}^{2}\right)$. BMI is used in preference to other bodyweight/height indices, including weight/height ratio, Ponderal Index, Benn Index. It widely used internationally to classify overweight and obesity among adults (5). According to Kementerian Kesehatan (6), BMI status classified as follows: underweight [severely wasted $\left(<17,0 \mathrm{~kg} / \mathrm{m}^{2}\right)$ and wasted $\left.\left(17-<18,5 \mathrm{~kg} / \mathrm{m}^{2}\right)\right]$, normal $(18,5-25,0$ $\left.\mathrm{kg} / \mathrm{m}^{2}\right)$, overweight $\left(25,0-27,0 \mathrm{~kg} / \mathrm{m}^{2}\right)$, obesity $\left(>27,0 \mathrm{~kg} / \mathrm{m}^{2}\right)$.

\section{Waist Circumference as an Indicator of Obesity}

Waist Circumference (WC) can be used as an estimated replacement for abdominal fat. A person can be said to be central obesity if he has a waist circumference $>90 \mathrm{~cm}$ for men and $>80$ $\mathrm{cm}$ for women (7).

Several studies have shown that waist circumference itself has a better correlation with abdominal fat, measured by computer tomography or with dual X-ray absorptiometry (DXA), compared to the ration of WC to hip. In a Canadian study among 151 adults, it was reported that there was a higher correlation between the area of abdominal visceral fat and WC compared with the correlation with the waist-hip circumference ratio. WC is also more strongly associated with total body fat, measured by densitometry, than by waist-to-hip circumference ratio. Furthermore, because the waist-to-hip circumference ratio is a ratio, it causes more problems concerning statistical analysis and interpretation (5).

\section{The Correlation of Uric Acid Levels with Body Mass Index and Waist Circumference}

High levels of leptin in obese people can cause uric acid disruption through urine so that uric acid levels in the blood of obese people become high (Fauzia, 2013). BMI above $25 \mathrm{~kg} / \mathrm{m}^{2}$ is one of the main components associated with increased uric acid in men, and also shows a significant correlation with uricemia. BMI also shows a positive relationship with leptin concentration, which is a trigger factor in increased uric acid levels. Individuals with high BMI can show insulin resistance, TG alteration, and blood pressure, and all of this is related to increased uric acid levels $(8,9)$.

According to Juraschek's study (2013), American adults also showed that uricemia related to their BMI value. At Normative Aging Study, weight gain is associated with an increased uric acid levels which can lead to a risk factor of hyperuricemia and gout. In a cohort prospective study among men, the higher BMI and weight gain are a strong risk factor for hyperuricemia while weight loss is a protective factor (10).

As we know that BMI is one of the indicators of obesity, while obesity often thought to influence the incidence of gout by increasing uric acid levels in the blood. People with obesity 
usually have metabolic syndrome which is increasing uric acid blood levels because of the increas of triglyceride concentration and decreasing uric acid excretion (arterial hypertension) (8).

WC also closely related potentially to atherogenic metabolic disorders associated with abdominal obesity to waist-to-hip circumference ratios. Thus, WC nowadays is the preferred anthropometric measurement for abdominal fat assessment (7). This method is an easy and inexpensive assessment method, and this is not related to height. This is also considered to be the most easily practiced anthropometric measurement for measuring abdominal fat in patients before and during weight loss treatments (5). Based on the results study of Lin et al among Taiwanese men, a WC of $94 \mathrm{~cm}$ can be a risk of gout (10).

\section{CONCLUSION}

The changes in metabolism in the body can trigger the increase of uric acid levels which can lead to a precursor of hyperuricemia and gout disease that can result in extreme pain in the joint. Based on the study, it has known that uric acid levels can be caused by obesity, protein intake, lifestyle, and others. The anthropometric methods which usually used to measured obesity is body mass index (BMI) and waist circumference (WC). BMI is one of the indicators of obesity, while obesity often thought to influence the incidence of gout by increasing uric acid levels in the blood. WC also closely related potentially to atherogenic metabolic disorders associated with abdominal obesity that to waist-to-hip circumference ratios.

\section{ACKNOWLEDGMENT}

Thank you to Universitas Muhammadiyah Jakarta and Universitas Indonesia for the opportunity and support during the writing of this article.

\section{CONFLICT OF INTEREST}

We have no conflict of interest, and no affiliation or connection to or with any entity or organization, which may raise a question of bias in discussion and conclusion of the manuscript.

\section{REFERENCE}

1. Newcombe DS. Uric Acid Metabolism in Humans. In: Gout: Basic Science and Clinical Practice. London: SpringerVerlag;

2. Manfredi JP, Holmes EW. Purine salvage pathways in myocardium. Annu Rev Physiol. Annual Reviews 4139 El Camino Way, PO Box 10139, Palo Alto, CA 94303-0139, USA; 1985;47(1):691705.

3. Dianati NA. Gout and hyperuricemia. J Major. 2015;4(3):82-9.

4. Astuti STW, Tjahjono HD. FaktorFaktor Yang Memengaruhi Kadar Asam Urat (Gout) pada Laki-Laki Dewasa di Rt 04 Rw 03 Simomulyo Baru Surabaya. Keperawatan. 2018;3(2).

5. Gibson RS. Principles of Nutritional Assessment. Oxford University Press; 2005.

6. Kementerian Kesehatan Republik Indonesia. Pedoman Gizi Seimbang. 2014 p. 1-99.

7. World Health Organisation (WHO). WHO | Waist Circumference and WaistHip Ratio. Report of a WHO Expert Consultation. Geneva, 8-11 December 2008. 2008;(December):8-11. Available from: http://www.who.int

8. de Oliveira E, Burini R. High plasma uric acid concentration: Causes and consequences. Diabetol Metab Syndr. 2012 Apr 4;4:12.

9. de Oliveira RB, Liabeuf $S$, Okazaki $H$, Lenglet A, Desjardins L, Lemke H-D, et al. The clinical impact of plasma leptin levels in a cohort of chronic kidney 
disease patients. Clin Kidney J [Internet]. 2012/01/01. Oxford University Press; 2013 Feb;6(1):63-70. Available from: https://pubmed.ncbi.nlm.nih.gov/27818 752

10. Lin W-Y, Lung C-C, Liu T-S, Jian Z-H, Ko P-C, Huang J-Y, et al. The association of anthropometry indices with gout in Taiwanese men. BMC Endocr Disord [Internet]. 2013;13(1):30. Available from: https://doi.org/10.1186/1472-6823-1330 